\title{
Greens bested in West German uranium processing plant debate
}

\section{Munich}

THE conservative Environment Minister of the German Land of Hesse has won a publicity victory and embarrassed the Green Party by closing down part of the uranium-processing company Nukem. The minister, Karl-Heinz Weimar (Christian Democrat), who took over from Green Joschka Fischer in April, announced the partial closing on 3 July.

Nukem, in the city of Hanau, was criticized for inadequate fire protection and other safety deficiencies in the part of the plant converting uranium into fuel elements for use in research reactors. Weimar calls this "the heart of the operation" at Nukem, which carries out contracts for customers in Britain, France and the United States as well as West Germany. The facility will stay closed until Nukem has complied with the regulations - probably no more than three or four weeks.

But Weimar also announced that he has submitted a 36-point catalogue of potential problems, not made public, to Nukem and asked for a response by 3 August. This is thought to include even stricter safety requirements, which Nukem may be hard pressed to adopt at short notice. The outcome may be an even longer shutdown.

Nukem has nevertheless said it is willing to comply immediately with the fire safety requirement. A partial shutdown will not affect business, said a Nukem official. The plant can continue to operate until September using uranium already converted, but a shutdown for longer than a month would be "very difficult". All Weimar's directives so far concern the older part of the Nukem operation. A new section, begun in 1982, is expected to replace the older one in 1989 or 1990.

Weimar's quick and decisive action, which has won him much favourable publicity in the West German press, derives from his pragmatic attitude, and that of his party, to the nuclear industry. The ruling coalition, led by the Christian Democratic Union wants to use nuclear power at least until a cheap alternative comes along. Demanding that Nukem operate safely is one way to get it out of the limelight.

The Greens, on the other hand, have been trying for years to have Nukem shut completely. Even now, they complain that Weimar's measures are superficial. The Greens would at least like to see comprehensive protection against earthquakes, aircraft crashes and terrorist acts.

But the Greens did not push for safety improvements when they held the environment portfolio from December 1985 to April 1987, on the grounds that that would have implied Green acceptance of the nuclear industry. The Green "fixation" on closing Nukem, said Green environment spokesman Chris Boppel, has led to the Greens' "self-destruction" in Hesse. The only Social DemocraticGreen coalition in history broke up earlier this year over the licensing of the new section of Nukem.

The Greens nevertheless take solace that they "started the avalanche" of public concern about Nukem in the early 1980 s. Their complaint that Nukem and its sister company Alkem had been operating illegally since 1975 has led to a lawsuit brought by the Hanau district attorney's office against the president of Alkem, another Alkem manager, and several former Social Democrat (SPD) officials. The defendants are charged with making six changes in Alkem procedures outside the guidelines of a "preliminary licence" granted by the SPD government in 1984 . The trial begins on 10 August.

Another pending lawsuit may have grave consequences for Nukem. According to Green spokesman Boppel, the Hanau district attorney is planning to indict three former cabinet ministers on charges of colluding with Nukem managers

The district attorney's office has refused to reveal the defendants in the case until the indictment becomes final Whether it can be proved that Nukem and Alkem have operated illegally is open to question.

Steven Dickman

\section{Canada aims to join remote sensing field with new satellite}

\section{Toronto}

CANAdA plans to go ahead with its first ambitious remote-sensing project - a radar sensor due to be put into an $800-\mathrm{km}$ Earth orbit in 1994. So much is clear from the announcement by science minister Frank Oberle that many financial details of the C\$725 million Radarsat project have now been settled. Formal cost sharing agreements with the United States and Britain should be completed by late fall.

It was no accident that Canada was among the first countries in the world to embrace the space age. As a large country dependent on natural resources, with a small, dispersed population and many remote, undeveloped regions, it was tailor-made for the benefits of spacebased technologies such as communications and remote-sensing satellites. In 1972 , the same year Canada became the first country to put a communications satellite in orbit exclusively for domestic use, it built the first non-US ground station to receive Landsat data.

In the following 15 years, Canadian companies became leaders in groundbased receiving and image-processing and data-analysis technologies, capturing an export market worth some $\mathrm{C} \$ 60$ million annually through sales and services to more than 100 countries.

Radarsat will be able to collect data at night and through clouds - critical for reliable coverage of Canadian territory, especially in the north - by using an advanced synthetic aperture radar, a technique that uses the spacecraft's own motion in processing radar signals reflected from Earth. Radarsat will have multiple, adjustable beams able to resolve objects from $100 \mathrm{~m}$ to $10 \mathrm{~m}$ in size, smaller than the US Landsat and the French
SPOT. The satellite will be used to collect data on crops, forests, mineral resources, Arctic ice, sea state and weather conditions. The Canadian government also views it as an important tool for monitoring shipping in Arctic waters and asserting sovereignty in the north.

Canada is taking the lead in the 10-year, C $\$ 725$ million programme, but Britain and France are expected to provide some 40 per cent of that total in return for a share of the data, according to Oberle. British Aerospace plc will provide the spacecraft structure, worth an estimated C\$197 million, and the United States will provide launch services. Canada will build the radar and the data-collection system and will manage data-gathering and analysis.

Oberle says the private sector is planning to establish a consortium to market and distribute the data, which will be sold to Canadian federal and provincial government agencies, foreign countries, corporations and individuals. The sale of data is expected to defray part of the $C \$ 10$ million annual operating costs. If projected sales of $\mathrm{C} \$ 150$ million over the satellite's five-year lifetime materialize, the consortium will return $\mathrm{C} \$ 34$ million in royalties to the government.

When the Canadian cabinet first considered its budget, the project was competing with two other big items - M-Sat, a mobile communications satellite, and the robotic servicing system Canada plans to contribute to the US/international space station. Decisions in favour of the other two projects all but orphaned Radarsat, and its survival depended on the ability of proponents to put together a new coalition of public, private and international support.
Lydia Dotto 